\title{
Contaminant levels in the European eel (Anguilla anguilla) in North Rhine-Westphalian rivers
}

\author{
Barbara Guhl", Franz-Josef Stürenberg and Gerhard Santora
}

\begin{abstract}
Background: Populations of the European eel (Anguilla anguilla) are declining rapidly and are now considered below safe biological limits. High pollution levels are one of the possible reasons for this decline. Contaminant levels are also of concern with regard to human consumption. This study examined the contamination levels of eels from the North Rhine-Westphalian catchment area of the Rhine and from adjacent rivers. A total of 119 eels from 13 sampling sites were analysed for polychlorinated dibenzo-p-dioxins and furans (PCDD/PCDFs), polychlorinated biphenyls (PCBs), polybrominated diphenyl ethers (PBDEs), mercury, perfluorooctane sulfonate (PFOS) and hexachlorobenzene (HCB).

Results: North Rhine-Westphalian eels had very high levels of contaminants comparable to eels from other European water bodies which are strongly influenced by anthropogenic activities. Mean values for PCDD/PCDFs ranged between 0.5 and $5.4 \mathrm{pg} \mathrm{WHO}_{2005}$ toxicity equivalents (TEQ)/g, for PCDD/PCDF + dl-PCBs between 6.3 and $44.7 \mathrm{pg} \mathrm{WHO} 2005 \mathrm{TEQ} / \mathrm{g}$, for indicator PCBs between 165 and 1,630 ng/g wet weight (ww), for 6 PBDEs between 9.2 and $242 \mu \mathrm{g} / \mathrm{kg}$ ww, for mercury between 0.069 and $0.314 \mathrm{mg} / \mathrm{kg} w w$, for PFOS between 8.3 and $49 \mu \mathrm{g} / \mathrm{kg} w w$ and for HCB between 3.4 and $50 \mu \mathrm{g} / \mathrm{kg}$ ww. For certain sampling sites, high contamination contents of the eels could be attributed to local sources. Congener patterns for PCBs and PBDEs were described, and biota to suspended matter ratios were calculated.

Conclusions: Pollution levels in eels from North Rhine-Westphalia are declining with regard to some contaminants but are still very high. Due to the high contaminant contents, eels from the rivers investigated are not suitable for human consumption. Furthermore, the concentrations of endocrine disrupting contaminants such as PCBs, PCDD/PCDFs and PBDEs in the eels are in a range which might have deleterious effects on the eel populations.
\end{abstract}

Keywords: Biota monitoring; Contaminant levels; Dioxins; PCB; HCB; PBDE; PFOS; Mercury; European eel (Anguilla anguilla)

\section{Background}

The European eel (Anguilla anguilla L.) used to be an abundant species but since the beginnings of the 1980s, populations have been declining sharply [1]. Amongst the possible reasons for this decline are over exploitation, habitat loss [2], migration barriers [3], the introduction of pathogens such as Anguillicoloides crassus [4] and adverse effects of contaminants $[5,6]$.

Due to their high body lipid content and due to ecological features such as a bottom dwelling way of life, longevity and a predatory feeding mode eels are particularly prone to bioaccumulate lipophilic contaminants.

\footnotetext{
* Correspondence: barbara.guhl@lanuv.nrw.de

North Rhine-Westphalian State Agency for Nature, Environment and Consumer Protection, Leibnizstr 10, 45659 Recklinghausen, Germany
}

Polychlorinated biphenyls (PCBs) and polychlorinated dibenzo-p-dioxins and furans (PCDD/PCDFs) especially have been suspected to impair aquatic organisms due to their endocrine disrupting mode of action [7]. Eels are thought to starve during their 6 months journey to their spawning grounds in the Sargasso Sea. The lipid reserves of the body are released, and the contaminants stored in the lipid tissue are put into circulation again [8]. Thus, during the migration, $\mathrm{PCBs}$ and PCDD/PCDFs may reach harmful concentrations in the blood [9]. Polybrominated diphenyl ethers (PBDEs) are another group of pollutants which are also potential endocrine disruptors. In vitro tests have demonstrated various agonistic and antagonistic activities of PBDEs with respect to the aryl hydrocarbon receptor and androgen receptor and to a lesser extend to

\section{空}


the estrogen and progesterone receptors [10-12]. They are additionally suspected to effect neurobehavioral development [13]. Other contaminants which are objects of scientific investigations due to recent legal regulation are perfluorooctane sulfonate (PFOS), hexachlorobenzene (HCB) and mercury. For PFOS, numerous effects are reported, e.g. hepatic damage, disturbance of DNA metabolism [14] and adverse effects on protein expression [15]. Hoff et al. [16] found evidence that HCB has an impact on various blood parameters. Like other metal pollutants, mercury has been demonstrated to impair general fitness as assessed by Fulton's condition factor and to display immunotoxic effects $[17,18]$.

Contaminants in biota have been subject of EU Regulation due to their potential adverse effects on predatory species (secondary poisoning) and on human health. EU Directive 2013/39/EU sets environmental quality standards (EQS) for 11 priority substances in biota, amongst others, for the above-mentioned parameters mercury; $\mathrm{HCB}$; PCDD/PCDFs; dioxin-like PCBs (dl-PCBS); the sum of the six indicator PCBs 28, 52, 101, 138, 153 and 180; the sum of the BDE congeners 28, 47, 99, 100, 153 and 154 and PFOS, which have to be met by 2018 .

Contaminants in eels have been monitored extensively with a particular emphasis on PCDD/PCDFs and PCBs. For example, low toxicity equivalents (TEQ) of PCDD/ PCDFs + dl-PCBs, mostly not exceeding the EQS $\mathrm{E}_{\text {biota }}$ of $6.5 \mathrm{ng} \mathrm{WHO}_{2005}$-TEQ/kg set by EU Directive 2013/39/ $\mathrm{EU}$, were reported from the Loire [7], and high concentrations, in the range of 20 to nearly $100 \mathrm{ng} \mathrm{WHO}_{2005^{-}}$ $\mathrm{TEQ} / \mathrm{kg}$, were detected in eels from contaminated sites such as the Elbe near the port of Hamburg [19] and from certain Belgian rivers [5]. To protect the human health, EU Regulation 1259/2011 sets a maximum level of $300 \mathrm{ng} / \mathrm{g}$ ww for the indicator PCBs. In a review, Tapie et al. [20] presented data for the concentration of the six indicator PCBs + PCB 118 which ranged from $<10 \mathrm{ng} / \mathrm{g}$ ww in Irish waters to well over $1,000 \mathrm{ng} / \mathrm{g}$ ww in the Dutch Haringvliet and in the Rhone. About half of the studies considered in the review reported concentrations exceeding the EU EQS.

Generally, PBDE concentrations monitored in fish were two to four orders of magnitude higher than the new biota $\mathrm{EQS}_{\text {biota }}$ of $0.0085 \mu \mathrm{g} / \mathrm{kg}$ ww. Tapie et al. [20] also compiled data about BDE-47 which is usually three-fourths of the sum of 6 PBDE. The data were reported for different fish species and ranged from $<0.001 \mu \mathrm{g} / \mathrm{kg}$ ww in nearnatural Irish waters to $25 \mu \mathrm{g} / \mathrm{kg}$ ww in the Netherlands. Even higher values from Dutch waters were reported from Pujolar et al. [21] who measured a mean concentration of $92 \mu \mathrm{g} / \mathrm{kg}$ ww (sum of ten PBDEs) in female silver eels from the highly polluted Dessel Schoten Canal. Sühring et al. [22] analysed nine PBDEs in silver eels from the upper part of the Rhine and found a mean concentration of $21.3 \mu \mathrm{g} / \mathrm{kg}$. Silver and yellow eels from the Elbe contained an average of 8.3 and $8.9 \mu \mathrm{g} / \mathrm{kg}$, respectively.

$\mathrm{HCB}$ concentrations detected in eel were mostly below the EU EQS biota $_{\text {of }} 10 \mu \mathrm{g} / \mathrm{kg}$, e.g. [23] but also under exceptional circumstances up to concentrations of $192 \mu \mathrm{g} /$ $\mathrm{kg}$ [24]. Mercury was well above the EQS biota of $20 \mu \mathrm{g} / \mathrm{kg}$ $w w$ in all monitoring studies but usually below the limit for human consumption of $1 \mathrm{mg} / \mathrm{kg}$ ww set by the EU Commission Regulation 1881/2006. Noël et al. [25] compiled data on $\mathrm{Hg}$ concentrations in eels from European waters which ranged between 10 and $800 \mu \mathrm{g} \mathrm{Hg} / \mathrm{kg}$ ww.

EU Directive 2013/39/EU sets an EQS biota $_{\text {for PFOS of }}$ $9.1 \mu \mathrm{g} / \mathrm{kg}$ ww. In a review, Hloušková et al. [26] reported values for the sum of perfluoroalkyl substances (PFASs) in fish (PFOS normally comprises at least $90 \%$ of the PFASs present) in a range of 0.2 to up to $1,963 \mu \mathrm{g} / \mathrm{kg}$ ww. The highest values were reported from polluted Czech rivers. Data on PFOS concentrations in eel are scarce. Only data on PFOS contents in the liver have been published. Roland et al. [15] determined mean liver concentrations of $31.1 \mu \mathrm{g} / \mathrm{kg}$ in a relatively unpolluted canal and 230.1 and $329.9 \mu \mathrm{g} / \mathrm{kg}$ for two polluted sites. Hoff et al. [16] measured mean hepatic PFOS concentrations of $1,387 \mu \mathrm{g} / \mathrm{kg} w w$ in eels from four Belgian water bodies which are heavily polluted and related to the high concentrations to fluorochemical production units in the vicinity of the sampling sites.

The objectives of this study were the description of contamination patterns in eels from the North RhineWestphalian Rhine region with respect to the EU priority substances and the evaluation of the potential risk to the eel populations as well as to human health via consumption of eels.

\section{Results and discussion}

Figure 1 depicts the location of the sampling sites in North Rhine-Westphalia (for further details see Methods). Table 1 sums up the information on the biometric data of the eels. On average eels were between 7 and 14 years old and differed accordingly in size and weight. Eels from the Sieg were relatively small (mean length $47 \mathrm{~cm}$, mean weight $203 \mathrm{~g}$ ). The oldest and heaviest eels were collected from the Niers (mean age 14 years, mean weight $861 \mathrm{~g}$ ). Despite these variations, the mean lipid content of all sampling sites did not differ significantly ( $\alpha=0.1$ ). For most sites, the condition factor varied between 0.17 and 0.22 which is a common range for healthy eels. Only eels from the Ruhr had an exceptionally high condition factor of 0.28 which can be attributed to the fact that the sample included three very old ( $>15$ years) and heavy eels. As additional information, it should be pointed out that more than half of all specimens had skin lesions, hematoma or other external signs of impaired physical health. 


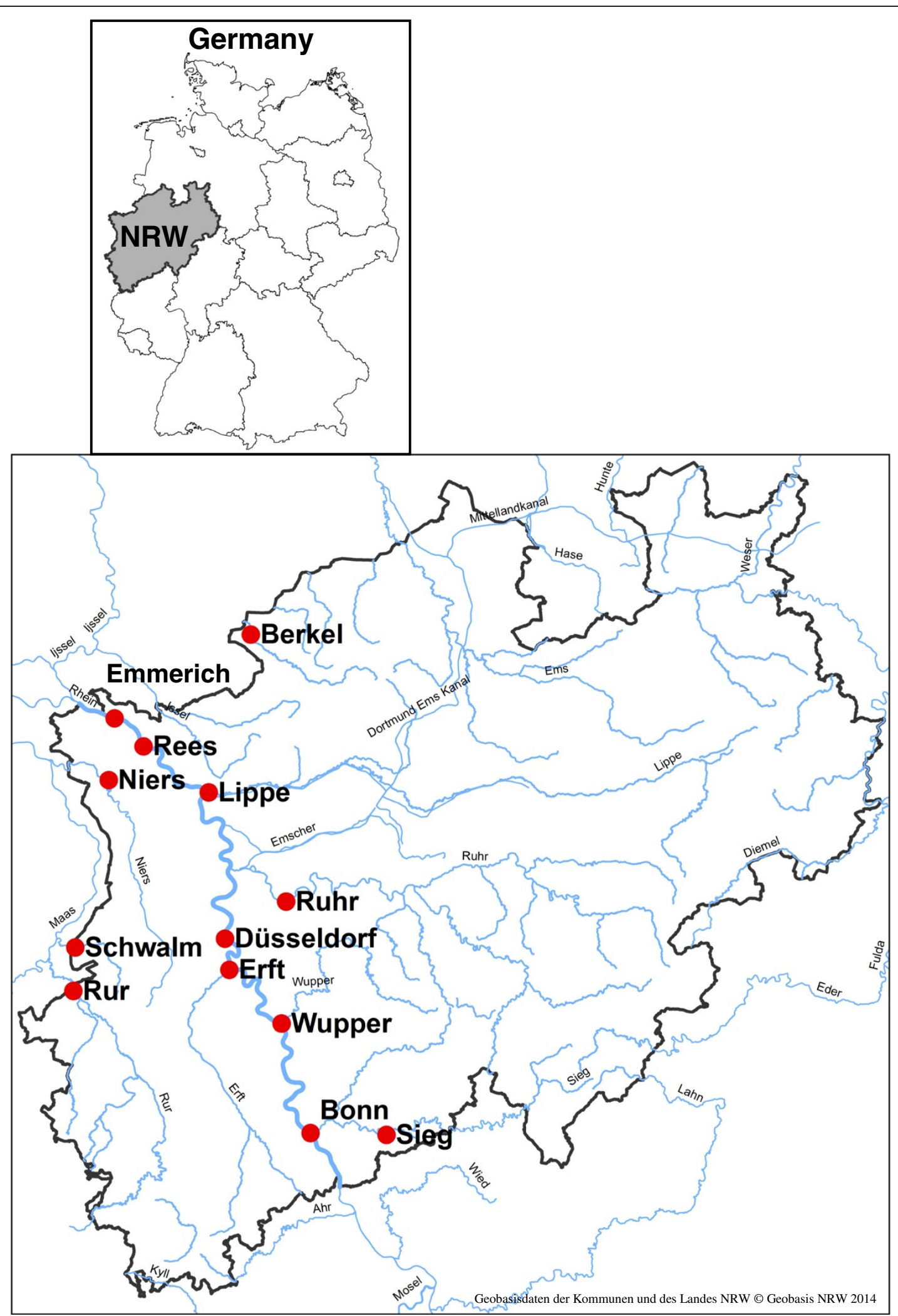

Figure 1 Location of sampling sites in North Rhine-Westphalia. 
Table 1 Arithmetic means and standard deviations for biometric parameters

\begin{tabular}{lclllll}
\hline Sampling site & $\boldsymbol{n}$ & Age (years) & Length $(\mathbf{c m})$ & Weight $(\mathbf{g})$ & Lipid content (\%) & Condition factor \\
\hline Rhein Bonn & 9 & $9.5 \pm 2.8$ & $59 \pm 12$ & $407 \pm 230$ & $22.9 \pm 9.7$ & $0.18 \pm 0.02$ \\
Rhein Düsseldorf & 11 & $7.1 \pm 1.8$ & $47 \pm 13$ & $250 \pm 169$ & $13.9 \pm 8.8$ & $0.22 \pm 0.08$ \\
Rhein Rees & 9 & $8.7 \pm 2.1$ & $62 \pm 10$ & $529 \pm 245$ & $22.7 \pm 5.8$ & $0.20 \pm 0.02$ \\
Rhein Emmerich & 11 & n.d. $^{\text {. }}$ & $60 \pm 10$ & $405 \pm 194$ & $26.7 \pm 11.2$ & $0.18 \pm 0.02$ \\
Sieg & 10 & $8.6 \pm 2.4$ & $47 \pm 7$ & $203 \pm 92$ & $13.8 \pm 8.0$ & $0.19 \pm 0.03$ \\
Wupper & 10 & $7.6 \pm 2.8$ & $49 \pm 11$ & $278 \pm 165$ & $18.9 \pm 8.8$ & $0.21 \pm 0.03$ \\
Ruhr & 9 & $13.0 \pm 4.0$ & $56 \pm 12$ & $632 \pm 604$ & $26.5 \pm 14.1$ & $0.28 \pm 0.17$ \\
Erft & 10 & $8.8 \pm 3.2$ & $47 \pm 8$ & $230 \pm 127$ & $23.4 \pm 12.6$ & $0.20 \pm 0.03$ \\
Lippe & 9 & $8.3 \pm 2.8$ & $52 \pm 10$ & $280 \pm 171$ & $21.6 \pm 11.8$ & $0.17 \pm 0.03$ \\
Niers & 5 & $14.0 \pm 4.6$ & $734 \pm 14$ & $861 \pm 395$ & $29.1 \pm 6.3$ & $0.20 \pm 0.02$ \\
Schwalm & 8 & $13.4 \pm 2.1$ & $67 \pm 8$ & $597 \pm 194$ & $20.8 \pm 7.8$ & $0.20 \pm 0.03$ \\
Rur & 10 & $12.2 \pm 2.3$ & $55 \pm 6$ & $316 \pm 116$ & $25.4 \pm 9.6$ & $0.19 \pm 0.04$ \\
Berkel & 8 & $9.0 \pm 4.3$ & $54 \pm 13$ & $375 \pm 252$ & $20.6 \pm 13.4$ & $0.19 \pm 0.03$ \\
\hline
\end{tabular}

${ }^{a}$ n.d. $=$ not determined.

Results for the sum of PCDDs and PCDFs; for indicator PCBs, HCB, PFOS, PBDEs and mercury are presented in Table 2. In the literature, contaminant concentrations are presented per wet weight (ww), dry weight or lipid normalised (lw). The main focus of this study was on a compliance check for priority substances according to EU Directive 2013/39/EU and on the investigation of a possible risk for human health. Therefore, contaminant concentrations are presented as arithmetic means per wet weight. Where necessary, for comparison with published data, results are converted to lipid normalised values.

\section{PCDDs, PCDFs and indicator PCBs}

Mean concentrations for the sum of PCDDs and PCDFs are generally below the EQS of Directive 2013/39/EU of $3.5 \mathrm{pg} \mathrm{WHO}_{2005} \mathrm{PCDD} / \mathrm{PCDF} \mathrm{TEQ} / \mathrm{g}$. Exceptions are the values for the Rhine sites Rees and Emmerich where mean concentrations reached 4.7 and 5.4 pg $\mathrm{WHO}_{2005} \mathrm{PCDD} /$ $\mathrm{PCDF} \mathrm{TEQ} / \mathrm{g}$, respectively (significantly different from all other sampling sites). In contrast, mean concentrations of the sum of $\mathrm{PCDD} / \mathrm{PCDF}+\mathrm{dl}-\mathrm{PCB}$ were nearly always above the EQS of $6.5 \mathrm{pg} \mathrm{WHO}_{2005} \mathrm{PCDD} / \mathrm{PCDF}+\mathrm{dl}-\mathrm{PCB}$ $\mathrm{TEQ} / \mathrm{g}$ and also above the maximum level of $10 \mathrm{pg}$ $\mathrm{WHO}_{2005} \mathrm{PCDD} / \mathrm{PCDF}+\mathrm{dl}-\mathrm{PCB} \mathrm{TEQ} / \mathrm{g}$ in EU Regulation

Table 2 Arithmetic means and standard deviations for chemical parameters

\begin{tabular}{|c|c|c|c|c|c|c|c|c|}
\hline & $n^{\mathrm{a}}$ & $\begin{array}{l}\sum \mathrm{PCDD} / \mathrm{PCDF} \\
\left(\mathrm{pg} \mathrm{WHO} \mathrm{WO05}_{20 \mathrm{TE} / \mathrm{g})}\right.\end{array}$ & $\begin{array}{l}\sum \mathrm{PCDD} / \mathrm{PCDF}+\mathrm{dl}-\mathrm{PCB} \\
\left(\mathrm{pg} \mathrm{WHO}_{2005} \mathrm{TEQ} / \mathrm{g}\right)\end{array}$ & $\begin{array}{l}\text { Indicator } \\
\text { PCB (ng/g) }\end{array}$ & HCB $(\mu \mathrm{g} / \mathrm{kg})$ & $\begin{array}{l}\sum \text { PBDE } \\
(\mu \mathrm{g} / \mathrm{kg})\end{array}$ & PFOS $(\mu \mathrm{g} / \mathrm{kg})$ & $\mathrm{Hg}(\mathrm{mg} / \mathrm{kg})$ \\
\hline Rhein Bonn & $9 / 9$ & $1.8 \pm 0.7$ & $17.0 \pm 5.9$ & $253 \pm 81$ & $23.2 \pm 14.7$ & $18.4 \pm 5.6$ & $22.9 \pm 9.8$ & $0.210 \pm 0.116$ \\
\hline Rhein Düsseldorf & $7 / 11$ & $1.2 \pm 0.7$ & $19.4 \pm 7.9$ & $382 \pm 152$ & $27.8 \pm 11.9$ & $20.7 \pm 9.9$ & $27.5 \pm 23.6$ & $0.165 \pm 0.057$ \\
\hline Rhein Rees & $9 / 9$ & $4.7 \pm 1.8$ & $39.4 \pm 12.9$ & $698 \pm 269$ & $35.7 \pm 12.8$ & $74.6 \pm 30.7$ & $13.7 \pm 9.9$ & $0.273 \pm 0.058$ \\
\hline Rhein Emmerich & $11 / 11$ & $5.4 \pm 2.3$ & $44.7 \pm 17.8$ & $982 \pm 302$ & $50.2 \pm 25.2$ & $76.2 \pm 28.2$ & $35.8 \pm 17.9$ & $0.195 \pm 0.059$ \\
\hline Sieg & $9 / 10$ & $0.5 \pm 0.3$ & $6.3 \pm 2.8$ & $165 \pm 60$ & $3.4 \pm 1.7$ & $9.2 \pm 4.0$ & $13.4 \pm 2.9$ & $0.069 \pm 0.021$ \\
\hline Wupper & $9 / 10$ & $0.8 \pm 0.3$ & $14.7 \pm 3.0$ & $369 \pm 88$ & $18.5 \pm 6.1$ & $14.3 \pm 3.4$ & $30.6 \pm 16.9$ & $0.314 \pm 0.131$ \\
\hline Ruhr & $8 / 9$ & $2.2 \pm 1.2$ & $32.2 \pm 16.6$ & $800 \pm 318$ & $17.1 \pm 6.5$ & $23.1 \pm 12.8$ & $32.0 \pm 14.3$ & $0.077 \pm 0.024$ \\
\hline Erft & $9 / 10$ & $1.5 \pm 0.8$ & $14.5 \pm 6.2$ & $301 \pm 93$ & $11.6 \pm 7.1$ & $13.6 \pm 6.6$ & $14.6 \pm 7.1$ & $0.075 \pm 0.070$ \\
\hline Lippe & $9 / 9$ & $1.1 \pm 0.5$ & $25.2 \pm 22.4$ & $507 \pm 544$ & $19.3 \pm 8.2$ & $241.9 \pm 143.7$ & $15.6 \pm 6.7$ & $0.146 \pm 0.061$ \\
\hline Niers & $5 / 5$ & $2.2 \pm 0.5$ & $28.6 \pm 6.0$ & $643 \pm 197$ & $11.6 \pm 2.2$ & $14.1 \pm 4.4$ & $49.0 \pm 12.5$ & $0.080 \pm 0.018$ \\
\hline Schwalm & $8 / 8$ & $1.00 \pm 0.4$ & $12.3 \pm 4.0$ & $216 \pm 75$ & $8.8 \pm 3.1$ & $8.5 \pm 2.5$ & $16.9 \pm 7.0$ & $0.106 \pm 0.039$ \\
\hline Rur & $10 / 10$ & $2.1 \pm 1.2$ & $39.6 \pm 26.4$ & $1,630 \pm 762$ & $12.1 \pm 4.8$ & $53.4 \pm 30.4$ & $42.3 \pm 32.5$ & $0.124 \pm 0.030$ \\
\hline Berkel & $7 / 8$ & $1.2 \pm 1.3$ & $15.8 \pm 10.2$ & $357 \pm 377$ & $6.2 \pm 4.3$ & $20.8 \pm 22.6$ & $8.3 \pm 3.0$ & $0.145 \pm 0.067$ \\
\hline
\end{tabular}

${ }^{a}$ The first figure represents the number of data for HCB and PFOS, and the second figure represents the number of data for PCDD/PCDFs, dl-PCBs, indicator PCBs, PBDEs and $\mathrm{Hg}$. 
1259/2011. Highest mean TEQ concentrations were determined for eels from Emmerich (44.7 pg $\mathrm{WHO}_{2005} \mathrm{PCDD} /$ $\mathrm{PCDF}+\mathrm{dl}-\mathrm{PCB} \mathrm{TEQ} / \mathrm{g}$ ), Rees (39.4 pg $\mathrm{WHO}_{2005} \mathrm{PCDD} /$ $\mathrm{PCDF}+\mathrm{dl}-\mathrm{PCB} \mathrm{TEQ} / \mathrm{g})$, the Rur (39.6 pg PCDD/PCDF+dl$\left.\mathrm{PCB} \mathrm{WHO}_{2005} \mathrm{TEQ} / \mathrm{g}\right)$ and the Ruhr (32.2 $\mathrm{pg} \mathrm{WHO}_{2005}$ PCDD/PCDF+dl-PCB TEQ/g). Only eels from the Sieg had a mean concentration below the EQS (6.3 pg $\mathrm{WHO}_{2005}$ PCDD/PCDF+dl-PCB TEQ/g). These low concentrations cannot be attributed to the relatively low lipid contents of the Sieg eels as lipid normalised values are still low. The Rhine sites Rees and Emmerich and the Rur differed significantly from most other sites, but not from the Wupper, Ruhr, Niers and Lippe.

Similar TEQ concentrations were reported from Belgian waters [5] and from the Elbe in Germany [19]. Dioxin and dl-PCB levels were lower in the Loire (mean concentration 4.4 pg $\mathrm{WHO}_{2005} \mathrm{PCDD} / \mathrm{PCDF}+\mathrm{dl}-\mathrm{PCB} \mathrm{TEQ} / \mathrm{g}$, [7]) and in Irish rivers $\left(0.49\right.$ to $4.9 \mathrm{pg} \mathrm{WHO}_{1998} \mathrm{PCDD} / \mathrm{PCDF}+\mathrm{dl}-$ PCB TEQ/g [27]).

TEQ concentrations for dl-PCBs were 8 to 16 times higher than TEQ concentrations for PCDD/PCDFs. The highest ratio was found for the Wupper with a mean value of 18.5. In eels from European waters, dl-PCB contamination is usually of higher importance than PCDD/ PCDF contamination. High concentrations of dl-PCBs were e.g. also found in eels from Flemish waters [5], from the catchment area of the Elbe [19] and the Tiber in Rome [28]. In contrast, McHugh et al. [27] reported dlPCB concentrations between 0.17 and 1.24 pg $\mathrm{WHO}_{1998}$ dl-PCB TEQ from relatively clean Irish rivers and therefore ratios between dl-PCBs and PCDD/PCDF of 0.1 to 4.3 . Knutzen et al. [29] found PCDD/PCDF concentrations between 5.0 and $22.9 \mathrm{pg} \mathrm{WHO}_{1998}$ PCDD/PCDF TEQ and dl-PCB concentrations between 1.4 and 3.9 pg $\mathrm{WHO}_{1998}$ dl-PCB TEQ in Norvegian fjords which had been contaminated by discharges of waste water from a magnesium factory in the past.

All values recorded were well above the value of $4 \mathrm{pg}$ PCDD/PCDF + dl-PCB WHO $\mathrm{WH}_{199} \mathrm{TEQ} / \mathrm{g}$ which was determined by Palstra et al. [30] as a threshold value for adverse effects on the reproductive system of eels.

For indicator PCBs, the mean concentrations exceeded the maximum level for human consumption of $300 \mathrm{ng} / \mathrm{g}$ at most sampling sites. Exceptions were the eels from the Schwalm and the Sieg with 215 and $165 \mathrm{ng} / \mathrm{g}$, respectively. Values in the Rhine eels ranged from $253 \mathrm{ng} / \mathrm{g}$ in Bonn to $982 \mathrm{ng} / \mathrm{g}$ in Emmerich. They are well below the concentrations found in Rhine eels in 1995 and 1998/2000 by Heinisch et al. [31]. All results in their paper are presented only as graphs and therefore approximations. Values for eels in Bonn were over $500 \mathrm{ng} / \mathrm{g}$ in 1995 and even over $600 \mathrm{ng} / \mathrm{g}$ in 1998/2000. Concentrations in Emmerich were about 1,500 in 1995 and 1,200 ng/g in 1998/2000, respectively. This comparison with our dataset documents a decrease of PCB pollution reflecting the general reduction of PCBs present in the atmosphere as well as a lower availability of PCBs in the Rhine after changes in production processes in major industrial sites in North RhineWestphalia.

By far the highest PCB concentrations were determined for eels from the Rur (mean concentrations of 1,630 ng/g). The catchment area of the Rur has a mining history. According to Detzel et al. [32], hydraulic fuel used in the mining industry has been a major source for PCB release into the environment. Additionally, PCB concentrations in the Rur were influenced by the emissions of paper industry upstream the sampling site. The high PCB concentrations in eels from the Rur were also described by de Boer et al. [33] who investigated the contamination of Dutch eels over a period of 30 years. For the Dutch part of the Rur, they reported concentrations of the sum of indicator PCBs + PCB 118, which decreased between 1982 and 2006 from 44,372 to 7,087 ng/g lw and therefore considerably more than in the Rhine (mean concentrations of 1,630 ng/g ww for Rur eels from this study correspond to $6,668 \mathrm{ng} / \mathrm{g} \mathrm{lw})$. Generally, PCB concentrations in eels from North Rhine-Westphalian waters were in the range of values found in other European waters impacted by industry and dense human population. Tapie et al. [20] determined the sum of indicator PCBs + PCB 118 in eels from the Gironde values ranging between 1,141 and 5,746 ng/g lw. High concentrations were as well reported from eels in a Belgian canal which reached up to 8,700 ng/g ww [34] and from Flemish waters, where eels reach concentrations between 78 and $4,812 \mathrm{ng} / \mathrm{g}$ lw [35].

Concentrations of PCDD/PCDFs, indicator PCBs and dlPCBs were highly positively correlated with lipid content $(p<0.001)$ and also with age (PCDD/PCDFs $p=0.02$, indicator PCB $p=0.004$, dl-PCBs $p=0.003)$. But while PCDD/ PCDFs and dl-PCB were positively correlated with length $(p<0.001$ and $p=0.001$, respectively), indicator PCBs were not. Similarly, indicator PCBs were not correlated with weight (PCDD/PCDFs $p=0.012$, dl-PCBs $p=0.003$ ).

Dioxins, PCBs and other contaminants with endocrine disrupting properties may contribute to the decline of the eel populations [5]. Several studies tried to relate the contaminant burden of eels to enzymatic activity and transcriptomic responses. Pujolar et al. [21] found a correlation for the up-regulation of the transcription of genes associated with detoxification and a down-regulation of the transcription of genes associated with the oxidative phosphorylation pathway in eels with a PCB burden comparable to many North Rhine-Westphalian sites. Kammann et al. [36] investigated the ethoxyresorufin-O-deethylase (EROD) activity in eels from the Elbe and found that the EROD activity corresponded to PAH metabolite concentration in eel bile and to pollution levels from the sampling sites. 


\section{HCB}

Mean HCB concentrations exceeded the EQS of $10 \mu \mathrm{g} / \mathrm{kg}$ ww at most sampling sites. At the Sieg, all eels met the EQS (mean value $3.4 \mu \mathrm{g} / \mathrm{kg}$ ) and at the Berkel and Schwalm, more than $50 \%$ of all eels sampled complied with the EQS (mean values 6.2 and $8.8 \mu \mathrm{g} / \mathrm{kg}$, respectively). Along the Rhine, mean $\mathrm{HCB}$ concentrations increased from $23.2 \mu \mathrm{g} / \mathrm{kg}$ at Bonn to $50.2 \mu \mathrm{g} / \mathrm{kg}$ at Emmerich $(27.8 \mu \mathrm{g} / \mathrm{kg}$ at Düsseldorf and $35.7 \mu \mathrm{g} / \mathrm{kg}$ at Rees). Differences between Bonn and Emmerich were significant. Also, HCB concentrations differed significantly between the Rhine sites and the other rivers. The increasing HCB concentrations in eels along the Rhine can at least be partly attributed to former production processes of the chemical industry based in North Rhine-Westphalia. Although HCB concentrations were comparatively high in the Rhine, eels sampled in 2009 demonstrate a decrease of HCB over time which had already been detected in data compiled by Heinisch et al. [37] on HCB concentrations in Rhine eels from 1990/1991, 1995 and 1998/2000. As mentioned above, results in their paper are presented only as graphs and therefore approximations. They show a decrease from approximately $180 \mu \mathrm{g} \mathrm{HCB} / \mathrm{kg}$ in 1990 to $125 \mu \mathrm{g} / \mathrm{kg}$ in 2000 for eels from the Rhine site Emmerich. In our study, HCB concentrations in eels from this site were further reduced by about $60 \%$ to $50 \mu \mathrm{g} / \mathrm{kg}$. The reduction of the HCB contaminant levels in eels is also due to the fact that production of $\mathrm{HCB}$ in the chemical industry in the upper part of the Rhine catchment area ceased in the 1990s and that the use of HCB as a fungicide was banned in Germany in 1981.

Comparable values to the HCB concentrations in the Rhine or even higher concentrations have been determined in eels from Dutch waters. De Boer et al. [33] reported mean HCB concentrations of 22 to $243 \mu \mathrm{g} / \mathrm{kg}$ lw. The latter value originated from eels from the Dutch part of the Rhine from the year 2004. The corresponding mean concentrations from this study for Emmerich, south of the Dutch border, of $178 \mu \mathrm{g} / \mathrm{kg}$ lw and for Rees, further south of the border, $155 \mu \mathrm{g} / \mathrm{kg}$ lw are in good agreement with their results. At other European waters, HCB concentrations in eels were far lower, e.g. in Italian lagoons (1 to $4 \mu \mathrm{g} / \mathrm{kg}$ lw [6]) or Scottish waters where HCB levels often were below the quantification limit [23].

As expected from its lipophilic nature, HCB was positively correlated with lipid content $(p<0.001)$. It was also positively correlated with length $(p=0.006)$, but not with the other biometric parameters.

\section{Sum of PBDE}

The PBDE concentrations always exceeded the EQS of $0.0085 \mu \mathrm{g} / \mathrm{kg}$ ww for the substances established by EU Directive $2013 / 39 / \mathrm{EU}$ by a factor of $10^{3}$ to $10^{5}$ (range of mean concentrations 9.2 to $241.9 \mu \mathrm{g} / \mathrm{kg}$ ). Highest concentrations were found in eels from the Lippe, where an industrial complex with mainly chemical industry has been established for a long time. Means for the sampling sites Lippe $(241.9 \mu \mathrm{g} / \mathrm{kg})$, Rees $(74.6 \mu \mathrm{g} / \mathrm{kg})$ and Emmerich $(76.2 \mu \mathrm{g} / \mathrm{kg})$ - which are the Rhine sampling sites downstream of the confluence of the Lippe - differed significantly from all other sampling sites. Sühring et al. [22] investigated BDE47, BED-66, BDE-99, BDE-100, BDE-153, BDE-154 and BDE-183 in yellow and silver eels from the Elbe and in silver eels from the upper part of the Rhine and found mean values of 8.9 and $8.3 \mu \mathrm{g} / \mathrm{kg}$ for yellow eels and silver eels of the Elbe and $21.3 \mu \mathrm{g} / \mathrm{kg}$ for the Rhine. PBDE concentrations in the range of 10 to $100 \mu \mathrm{g} / \mathrm{kg}$ ww (sum of BDE-28, BDE-47, BDE-49, BDE-66, BDE-85, BDE-99, BDE-100, BDE-153, BDE-154, BDE-183 and BDE-209) have been reported from a number of Belgian waters [38], with a maximum value of $5,811 \mu \mathrm{g} / \mathrm{kg}$ lw (for comparison, Lippe $242 \mu \mathrm{g} / \mathrm{kg} w \mathrm{w}=1,242 \mu \mathrm{g} / \mathrm{kg} \mathrm{lw}$ ). In eels from 60 Flemish sites sums for 14 BDE congeners (mainly congeners 47, 99 and 100) ranged between 12 and 1,400 $\mu \mathrm{g} / \mathrm{kg}$ with a mean of $110 \mu \mathrm{g} / \mathrm{kg}$ [35]. PBDE concentrations from Irish waters were lower and ranged from 1.0 to $7.1 \mu \mathrm{g} / \mathrm{kg}$ ww for the sum of 11 PBDE congeners [27].

In this study, the sum of 6 PBDEs was significantly positively correlated with the lipid content $(p=0.006)$ and weakly negatively correlated with the condition factor $(p=0.05)$ but not with any other of the biometric parameters.

There is still few evidence for possible effects of PBDEs at environmental concentrations, but Tomy et al. [39] found evidence for lower plasma levels of thyroxine in Lake Trout with BDE concentrations similar to those found in eel from the Lippe and the Rhine sites Rees and Emmerich. Kierkegaard et al. [40] investigated the effects of BDE-209 on Rainbow Trout over a period of 120 days. They detected significantly reduced numbers of leucocytes and lymphocytes and an increase of liver weight. But they used high doses resulting in a 5 to 25 times higher body burden than the sum of PBDEs measured in the eels from North Rhine-Westphalia.

\section{PFOS}

Also, the PFOS concentrations often exceeded the EQS of $9.1 \mu \mathrm{g} / \mathrm{kg}$ ww with mean concentrations between 8.3 (Berkel) and $49.0 \mu \mathrm{g} / \mathrm{kg}$ (Niers). High concentrations were also found in the $\operatorname{Rur}(42.3 \mu \mathrm{g} / \mathrm{kg})$. Mean values from the Niers and the Rur differed significantly from most other rivers but not from the Rhine eels and those from the Wupper. Only five eels were collected from the Niers, so the mean value for this site should be interpreted with caution. Nevertheless, the high PFOS concentration could be taken as an indication of the high proportion of municipal waste water present in the Niers. In North Rhine-Westphalia, the main source for PFOS is the plating industry. Until 2008, PFOS was 
widely used as fire extinguishing agent [41]. PFOS is also often present in consumer goods. As mentioned above, the Rur has been affected by paper industry emissions. PFOS has been used in the production process of special papers which explains the high PFOS concentrations in eels from the Rur. For eels, only data on PFOS contents in the liver have been published which are of limited value for the interpretation of tissue concentrations. Roland et al. [15] determined mean liver concentrations between 31 and $390 \mu \mathrm{g} / \mathrm{kg}$ from eels collected from Belgian waters. Hoff et al. [16] measured mean hepatic PFOS concentrations of $1,387 \mu \mathrm{g} / \mathrm{kg}$ ww in eels from four heavily polluted Belgian water bodies and related them to the high concentrations to fluorochemical production units in the vicinity of the sampling sites. In this study, they found a strongly significant correlation between liver PFOS concentrations and serum alanine aminotransferase activity which they interpreted as indication for induction of hepatic damage. In North Rhine-Westphalia, a survey on PFOS in the muscle tissues of several fish species, with eel being one of them, was conducted [41]. The median concentration of all fishes from surveillance monitoring was $7.1 \mu \mathrm{g} / \mathrm{kg}$, and the median concentration from impacted sites was $24.4 \mu \mathrm{g} / \mathrm{kg}$. Hloušková et al. [26] investigated PFT levels in a mixed sample consisting mainly of bream (Abramis brama), European chub (Squalius cephalus) and Roach (Rutilis rutilus) and found a median concentration of $5.7 \mu \mathrm{g} / \mathrm{kg}$. The results of both studies indicate that the PFOS concentrations measured in eels during this study are comparatively high.

In this study, PFOS did not show any significant correlation with any of the biometric parameters.

\section{Mercury}

For mercury concentrations, in accordance with results from other European waters, all eels from North RhineWestphalia had concentrations below the EU limit for mercury in fish for human consumption $(1.0 \mathrm{mg} / \mathrm{kg} \mathrm{ww})$ but above the EQS of $20 \mu \mathrm{g} / \mathrm{kg}$ ww for secondary poisoning. Highest concentrations were measured in eels from the Wupper (mean concentration $0.314 \mathrm{mg} / \mathrm{kg}$ ) and the Rhine (Rees $0.273 \mathrm{mg} / \mathrm{kg}$, Emmerich $0.195 \mathrm{mg} /$ $\mathrm{kg}$, Bonn $0.210 \mathrm{mg} / \mathrm{kg}$ and Düsseldorf $0.165 \mathrm{mg} / \mathrm{kg}$ ) and lowest concentrations for eels from the Sieg $(0.069 \mathrm{mg} /$ $\mathrm{kg}$ ) The mean concentrations from the Wupper eels and from the Rhine eels at Rees differed significantly from most other sampling sites but not from each other. Eels in two Spanish rivers had comparable mean mercury concentrations between 0.155 and $0.533 \mathrm{mg} / \mathrm{kg}$ [42], and in Portuguese lagoons, eels contained between 0.55 and $0.285 \mathrm{mg} \mathrm{Hg} / \mathrm{kg}$ [43]. Noël et al. [25] reviewed further data from the studies in other countries including Poland, the Czech Republic, Germany, UK, Slovenia and Hungary and reported a range of values between 10 and
$800 \mu \mathrm{g} / \mathrm{kg}$. In their study of French rivers, they found mean concentrations of $0.199 \mathrm{mg} / \mathrm{kg}$ and reported a strong positive correlation between $\mathrm{Hg}$ concentration and the condition factor $(p<0.0001)$ but no correlation between $\mathrm{Hg}$ levels and body weight or length. In this study, mercury concentrations were significantly positively correlated with age $(p=0.029)$. Also, there was a weak positive correlation with length $(p=0.049)$ and weight $(p=0.055)$ but not with the condition factor. After a review of experimental data on $\mathrm{Hg}$ effects on fish, Sandheinrich and Wiener [44] estimated that the threshold value for negative effects of $\mathrm{Hg}$ on fish is between 0.3 and $0.7 \mathrm{mg} \mathrm{Hg} / \mathrm{kg}$ in the whole body homogenates which are at least about a quarter lower than the concentrations in the filet. Therefore, a deleterious effect of the $\mathrm{Hg}$ concentrations measured in the eels from this study is unlikely.

\section{PCB congener patterns}

Based on the eel data for PCB contamination, the Rhine sites Bonn and Emmerich and the Rur were chosen for a comparison between PCB congener patterns in eel and in the suspended matter from corresponding sampling sites. In the Rhine and the Rur, PCB 153 comprised 40\% to $43 \%$ of the sum of indicator PCBs in eel, PCB 138 accounted for $23 \%$ to $28 \%$ and PCB 180 for $12 \%$ to $16 \%$. PCB 101 and PCB 52 had a slightly higher proportion in eels from Emmerich (16\% and 8\%, respectively) compared to eels from Bonn and from the Rur (7\% to 9\% and 3\% to 5\%). PCB 28 did not exceed 1\% (Figure 2). The pattern of PCBs in suspended matter varied slightly with PCB 138 being the most dominant congener in the Rhine while in the Rur, PCB 153 had a slightly higher percentage than PCB 138. PCB 28 had mean percentages of $8 \%$ to $9 \%$ in suspended matter and therefore higher concentrations than in eels. According to Tapie et al. [20], PCB 153 is not regarded as being metabolisable and therefore an indicator for bioaccumulation. Müller et al. [45] examined PCB concentrations in eels and in sediment samples in the urban water bodies of the city of Berlin, Germany. They found similar PCB patterns in eels and in the sediment with PCB 138 and 153 dominating in eels and in the sediment while PCB 28 was more prominent in sediment samples compared to eel tissue. On the whole, PCB patterns in suspended matter and in biota found in this study were similar to PCB patterns in eels recorded from many European waters and also from North American water bodies reflecting the commercial PCB mixtures used in the past. Examples are data for eels from the Loire [7], from Scottish water bodies [23] and also for the American eel Anguilla rostrata from the Hudson River [46].

The bioconcentration ratio between contaminant content of suspended matter and eel tissue was calculated 


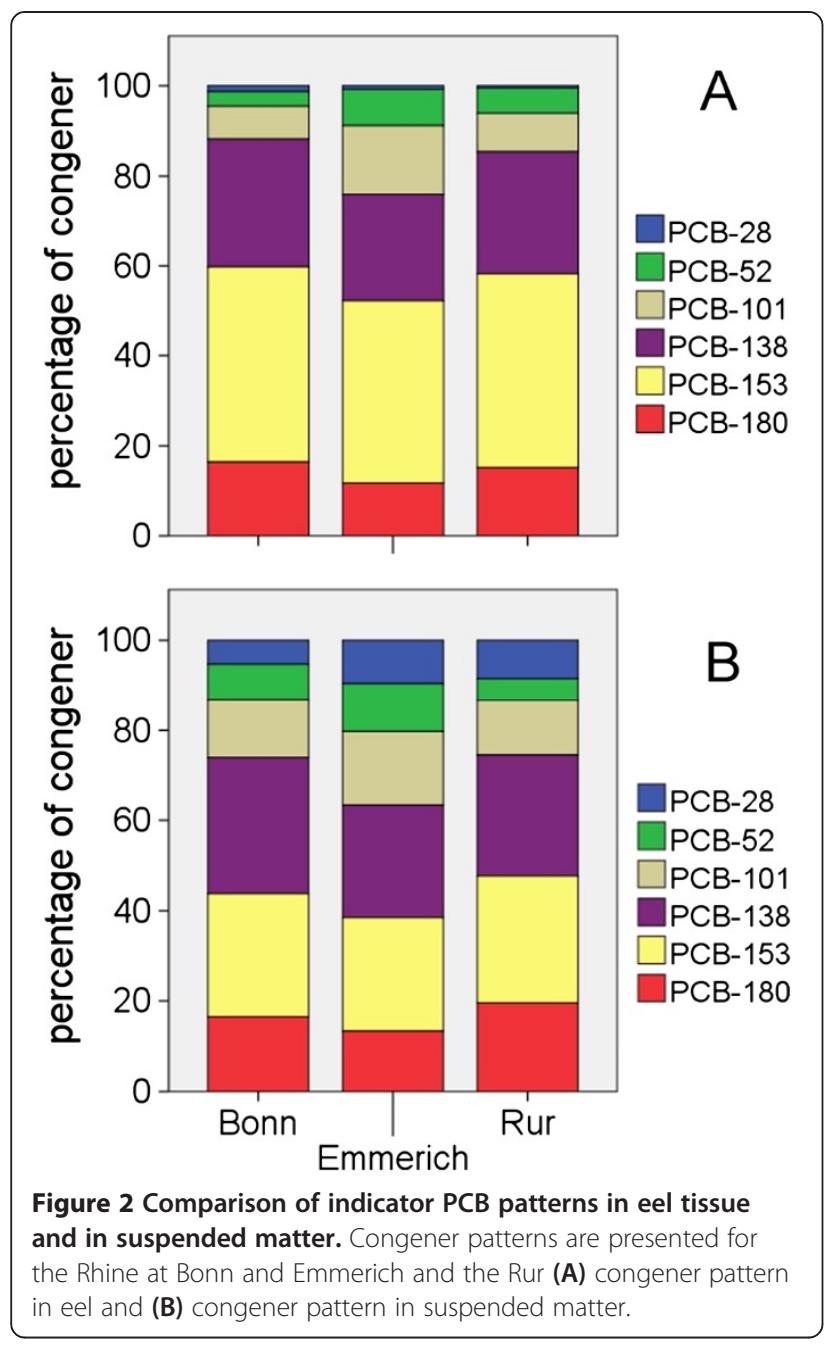

between PCB concentration of suspended matter expressed as dry weight and PCB concentration of eel expressed as dry weight and as lipid weight. The dry weight ratio for the Rhine at Bonn was 39 (76 for lw), at Emmerich 66 (116) and in the Rur 54 (92). Harrad and Smith [47] reported concentration ratios between sediment (normalised for the carbon content of the sediment) and eel tissue for individual PCB congeners in the range of $<1$ and 10. The ratios found in this study are far higher which might be explained by the 10 to $10^{2}$ higher PCB concentrations in North Rhine-Westphalian rivers compared to the River Severn investigated by Harrad and Smith [47]. As mentioned above, Müller et al. [45] also determined PCB concentrations in eels and in sediment samples from corresponding sampling sites. They expressed all eel data per wet weight (ww) and found a ratio of approximately 5 . The water bodies examined had comparable PCB levels to the suspended matter of the Rur. In this study, the dry weight of the eels investigated was approximately $30 \%$ of the wet weight. Based on this estimate, eels from Berlin waters had an eel to sediment ratio of approximately 15 which is still below the values found in this study.

Considering the 12 dl-PCB congeners, PCB 118 was clearly dominating with $50 \%$ to $67 \%$ of the sum of dlPCBs. PCB 105, 156 and 167 were present with 5\% to $15 \%$. All other PCB congeners were present in negligible concentrations (Figure 3). This congener pattern is quite common in eels from European waters and has also been reported, e. g. from Belgium [5] and Portugal [48].

\section{PBDE congener patterns}

PBDE patterns in eel and in suspended matter were compared for the Rhine sites Düsseldorf and Emmerich and the Lippe (Figure 4). Lippe eels had very high PBDE concentrations, and as a consequence, eels at the Rhine sites below the confluence of the Lippe had an elevated PBDE content. Therefore, the sampling sites at Düsseldorf upstream of the confluence of the Lippe and at Emmerich downstream of the Lippe were chosen to track a possible influence of the Lippe contamination on the Rhine. The comparison was limited to BDE-28, BDE-47, BDE-99, BDE-100, BDE-153, BDE-154 and BDE-209 as these were the only $\mathrm{BDE}$ congeners determined in suspended matter.

At all sites, BDE- 47 was the dominant congener with $60 \%$ to $62 \%$ at the two sites at the Rhine and $74 \%$ in the Lippe. BDE-100 was present with $28 \%$ to $30 \%$ in the Rhine and $17 \%$ in the Lippe. The other congeners were present in minor concentrations. A similar congener pattern with BDE-47 dominating and BDE-100 as the second most important congener was reported from the eel populations from the Scheldt [38], from the Elbe [49] and by Sühring et al. [50] for eel populations from several European rivers. In contrast, Sühring et al. [50] found equal concentrations of BDE-47 and BDE-100 in yellow eels from North America. They related this difference to the continuous exposition of American eels to technical penta- and octa-PBDE mixtures which had been banned in Europe in 2004. In contrast to the biota PBDE pattern, the Rhine suspended matter comprised almost exclusively of BDE209 (95\% to 97\%), reflecting the continuous use of deca$\mathrm{BDE}$ as fire protection agent in consumer goods. In the suspended matter of the Lippe, BDE-209 accounted for only $25 \%$, and BDE-99 and BDE-47 were present with 35\% and 24\%, respectively. This conspicuous PBDE pattern, which can be related to the influence of local chemical industry, did not lead to a change in the PBDE pattern in eels. Roosens et al. [51] investigated PBDE patterns in eels and in the sediment from various locations in Flemish water bodies. They also found high BDE-209 concentrations in the sediment and only rarely found elevated BDE209 concentrations in eels. They attributed this discrepancy to a poor uptake of BDE-209 from the sediment, a low solubility in water and a high degradation in the fish. The debromination of BDE-209 to lower brominated congeners 


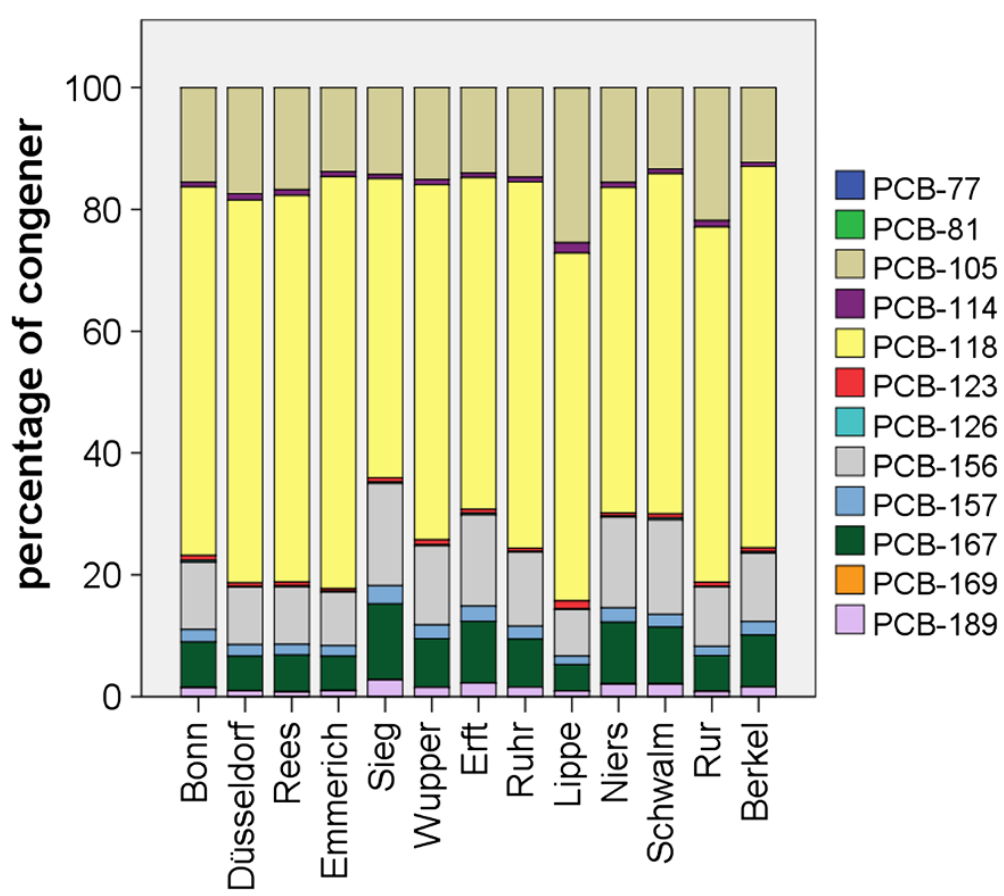

Figure 3 Comparison of dl-PCB patterns in eel tissue for all sampling sites.

has been described by several authors, e. g. [40,52-54] and seems to be a major source of penta-PBDEs in fish.

Ratios between PBDE concentrations in eel tissue and in suspended matter ranged between 0.6 (Düsseldorf) and 2.6 (Lippe) for eel dry weight and 1.5 (Düsseldorf) and 4.9 (Lippe) for eel lipid weight. These ratios are considerably lower than the ratios calculated for PCBs despite the fact that the sum of PBDEs was significantly positively correlated with the lipid content. The low ratios can be attributed to the poor transfer of BDE-209 congener from the suspended matter/sediment to the eels. This is in agreement with the higher eel to suspended matter ratios in the Lippe. According to Mariottini et al. [55], BDE-47 is considered to have the highest bioconcentration factor of PBDE congeners. In the Lippe suspended matter, BDE- 47 was present in approximately the same concentrations as BDE-209.

Figure 5 shows the pattern of BDE-28, BDE-47, BDE49, BDE-66, BDE-71, BDE-99, BDE-100, BDE-153, BDE154 and BDE-209 in eel tissue for all sampling sites. The pattern resembles the profile depicted in Figure 4 although additional BDE congeners were included in the calculation. At all sites, BDE-47 dominated the BDE pattern, with BDE-100 being the second most important congener. Together, these two congeners accounted for $85 \%$ to $94 \%$ of the BDEs measured.

\section{Conclusions}

Eels from North Rhine-Westphalian waters showed a high level of contamination. Over the last decades, $\mathrm{PCB}$ and HCB concentrations have decreased in the Rhine and its major tributaries and subsequently in eels and other fish but were still present in concentrations well above the EQS of the EU. In 2012, as a consequence of the high PCB contamination, the North Rhine-Westphalian government issued a recommendation not to consume wild eels from North Rhine-Westphalian waters [56].

Recent research has accumulated evidence that pollution may contribute to the decline of eel populations. For PCDD/PCDFs, PCBs and PBDEs, there are investigations indicating effects on the immune system, the reproductive system and the endocrine system of the fish. Due to the complex life cycle of eels and due to the large number of other simultaneously acting environmental factors, unequivocal evidence for the direct impact of pollutants on population dynamics is difficult. But it might be taken as an indication that the decrease in recruitment in the populations of the European eel during the last 30 years coincided with a strong intensification of agriculture and with the industrial production of a plethora of new substances.

Eels are prone to accumulate contaminants due to their high body lipid content, their longevity and their benthic way of life. Hence, the contamination levels of the eels in North Rhine-Westphalian waters reflected the contamination of the water bodies investigated. The influence from ambient contamination levels was particularly striking for eels from the four sampling sites at the Rhine as their contamination concentrations reflected the increasing pollution levels for most substances along the 


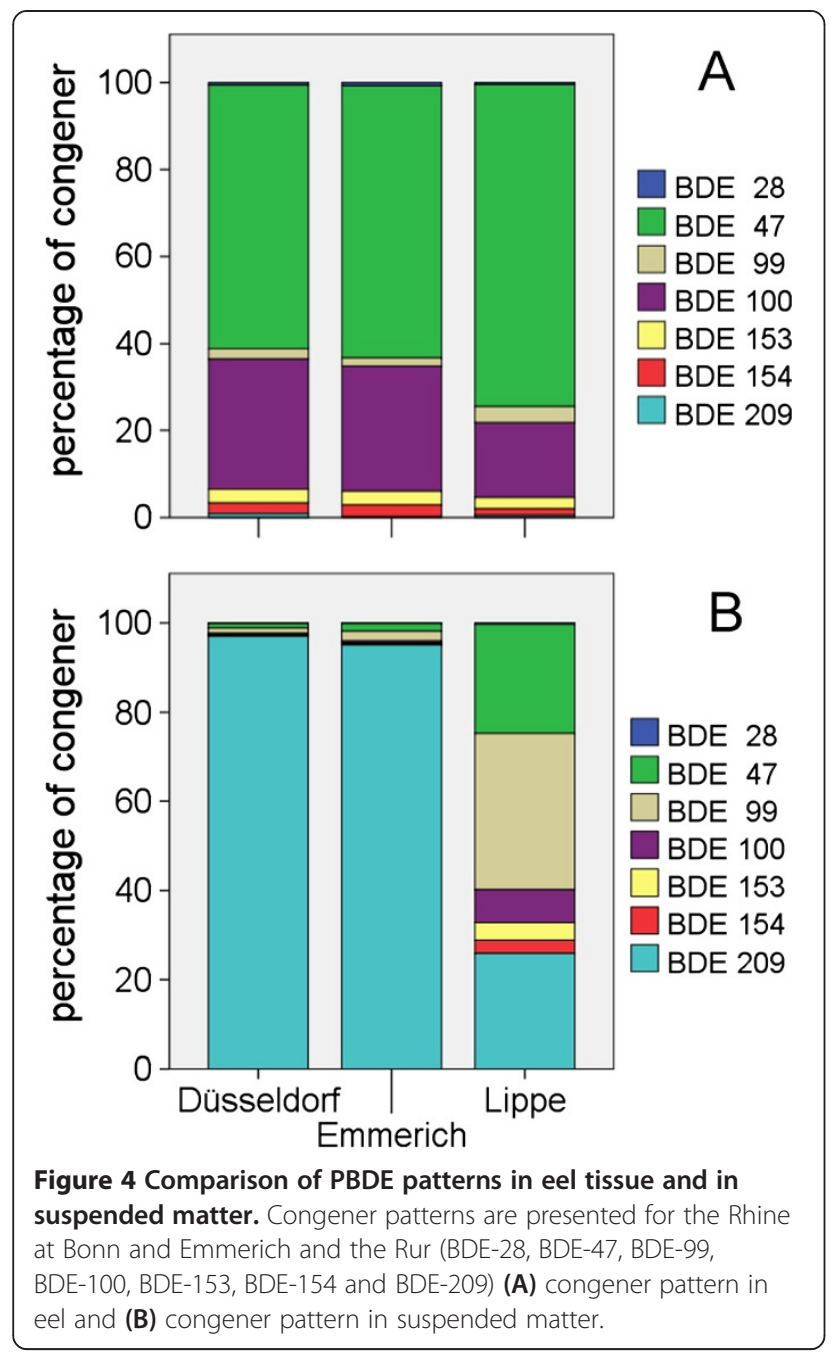

river course. For PBDEs, the rise of mean concentrations between Düsseldorf and Rees is a result of the load of the River Lippe, which reaches the Rhine between the two sampling sites. PFOS and mercury concentrations in eels did not increase along the North Rhine-Westphalian stretch of the Rhine. Contamination patterns at certain sampling sites could be traced back to local point sources as was shown for the conspicuous PCB pollution of the Rur.

\section{Methods}

\section{Sampling of eels}

In order to set up eel management plans in 2009 and 2010, the North Rhine-Westphalian government commissioned the Rhineland Fishery Association to carry out a survey of eel populations in ten major rivers. Eel populations were monitored using point abundance sampling with electrofishing equipment from a boat (electrofishing equipment EFKO FEG 8000, Leutkirch, Germany 8 KW, up to $600 \mathrm{~V}$, direct current, 60 points with a distance of $3 \mathrm{~m}$ between points). The length of each eel caught was measured before the eels were released again. As part of the survey, a subsample of 124 eels was collected from 13 sites in 10 rivers (Sieg, Wupper, Ruhr, Lippe, Erft, Rur, Niers, Schwalm, Berkel and four sites - Bonn, Düsseldorf, Rees and Emmerich - at the Rhine, Figure 1) for biometrical measurements and for inspection of the health status. Sites were generally situated in the downstream regions of the rivers, apart from the sites at the Rhine which covered the North Rhine-Westphalian stretch of the river. Usually, ten to eleven eels were taken, but as there were only small numbers of eels at the sampling sites at the Niers, the Schwalm and the Berkel five eels were taken at the Niers and eight eels at the Schwalm and the Berkel. The eels collected roughly represented the size-class distribution of the population at the sampling site. The eels were killed immediately by over narcotisation with $300 \mathrm{mg}$ Benzocain/l (Merck, Darmstadt, Germany), and transported frozen to the lab of the North Rhine-Westphalian State Agency for Nature, Environment and Consumer Protection (LANUV NRW). The sampling and killing was carried out by a licensed fish biologist. In the lab, the length, weight and sex were determined, and the condition factor was calculated (condition factor $C_{F}=$ weight $(\mathrm{g}) \times 100$ / length $\left.(\mathrm{cm})^{3}\right)$. Heads were dissected and sent to the Thünen Institute of Fisheries Ecology, Hamburg, Germany, where the age was determined using otolith preparation following ICES [57]. The developmental stage was determined using the eye index according to Durif et al. [58]. The eels were with very few exceptions in stages 1 to 3 . Eels from the Schwalm and from the lower Rhine were predominantly in stage 3 which is according to Durif et al. [58], the stage just before the onset of metamorphosis. At all other sampling sites, stages 1 to 3 were present in about equal numbers. It was decided to take tissue samples of the yellow eels for the analysis of contaminants. Five eels which were judged to be silver eels according to their eye index were excluded from further analysis (one each from the Ruhr, the Erft and the Rhine sites Bonn, Düsseldorf and Rees). Therefore, 119 eels altogether were chemically analysed. The left filet of each specimen was sampled, including the skin (at least $100 \mathrm{~g}$; from a large specimen, the middle part of the filet was chosen), and stored frozen.

\section{Analysis of eels}

In 2011, the tissue samples were analysed for PCDDs, PCDFs, PCBs, PBDEs, HCB, mercury, perfluorooctanoic acid (PFOA) and PFOS by Eurofins GfA Lab Service (Hamburg, Germany). Prior to further treatment for analysis of organic contaminants, eel samples were lyophilized and homogenised. For dry matter determination, lyophilised subsamples were subjected to a drying procedure at $103^{\circ} \mathrm{C}$ for at least $4 \mathrm{~h}$. Dry matter content was calculated 


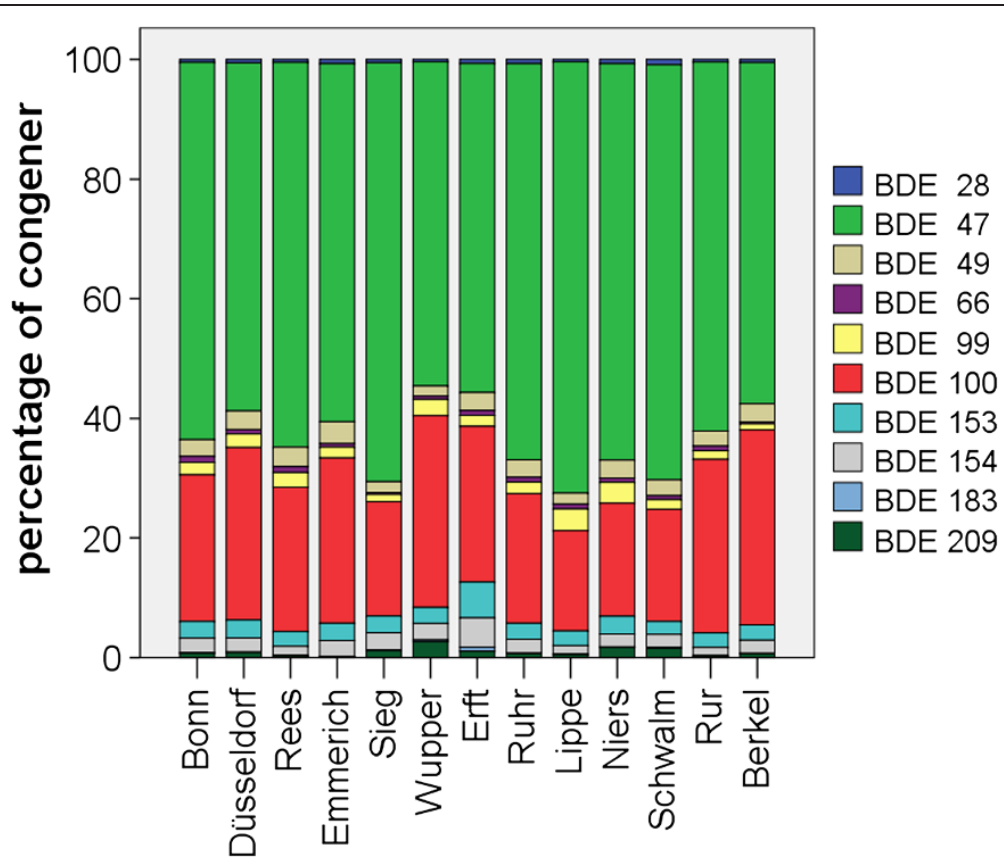

Figure 5 PBDE patterns in eel tissue from all sampling sites.

taking into account the dry matter content after lyophilisation as well as the dry matter after the drying procedure.

\section{PCDD/PCDFs, dl-PCBs and indicator PCBs}

In brief, samples were analysed for 17 2,3,7,8-substituted congeners of PCDDs and (PCDFs, $12 \mathrm{dl}$-PCBs and the 6 indicator PCBs 28, 52, 101, 138, 153 and 180 using highresolution gas chromatography and high-resolution mass spectrometry (HRGC/HRMS) analogue to a method described by Neugebauer et al. [59]. For each native PCDD/ PCDF and PCB congener to be determined, the corresponding ${ }^{13} \mathrm{C}_{12}$ - internal standard was added to the samples before the extraction procedure. After spiking, the samples were Soxhlet-extracted overnight with appropriate organic solvents for ultratrace-analyses (e.g. toluene). Lipid determination was performed gravimetrically in these crude extracts as extractable lipids. Subsequently, these extracts were subjected to a cleanup procedure using a multi-column chromatography system (involving carbon-on-glass fibre or carbon-on-celite for PCDD/PCDF and $\mathrm{PCB})$. Further ${ }^{13} \mathrm{C}_{12}$-labelled internal standards were added to the extracts for the determination of the recovery of the internal standards added before. Analyses were performed by HRGC/HRMS (Waters Autospec, Eschborn, Germany or DFS mass spectrometers, Thermo Fisher Scientific, Bremen, Germany). For each substance, two isotope masses were measured. The quantification was carried out by means of isotope dilution analysis with the use of internal and external standards. In addition to values for individual congeners, calculations of the TEQ according to the WHO-system 2005 [60] were carried out by taking into account the quantification limit for non-quantifiable compounds (upperbound procedure).

\section{PBDEs}

Samples were analysed for 24 congeners of PBDEs (including BDE-17, BDE-28, BDE-47, BDE-49, BDE-66, BDE-71, BDE-77, BDE-85, BDE-99, BDE-100, BDE-119, BDE-126, BDE-138, BDE-153, BDE-154, BDE-156, BDE-183, BDE184, BDE-191, BDE-196, BDE-197, BDE-206, BDE-207 and BDE-209) using gas chromatography and mass spectrometry (GC/MS) analogue to a method by Päpke et al. [61].

A mixture of ${ }^{13} \mathrm{C}_{12}$-labelled internal standards was added to the samples before the extraction procedure. After spiking, the samples were extracted by means of Soxhlet extraction using a mixture of appropriate polar and non-polar solvents for ultratrace-analyses (e.g. hexane/acetone). After extraction, a cleanup procedure was performed using concentrated sulfuric acid additionally to column chromatography involving activated silica gel resp. alumina. Further ${ }^{13} \mathrm{C}_{12}$-labelled internal standards were added to the extracts for the determination of the recovery of the internal standards added before. PBDEs were analysed by means of GC/MS. For each substance, two isotope masses were measured. The quantification was carried out by means of isotope dilution analysis with the use of internal and external standards.

As many of the BDEs analysed were always or almost always below the limit of quantification, only the results for BDE-28, BDE-47, BDE-49, BDE-66, BDE-99, BDE-100, 
BDE-153, BDE-154, BDE-183 and BDE-209 are presented in this publication.

\section{PFOS/PFOA}

A mixture of ${ }^{13} \mathrm{C}_{12}$-labelled internal standards was added to the samples before the extraction procedure. After spiking, the samples were extracted by means of ultrasonic extraction with appropriate polar solvents (e.g. methanol) for ultratrace-analyses (e.g. nanograde). After extraction, the cleanup was carried out involving carbon black. A further ${ }^{13} \mathrm{C}_{12}$-labelled internal standard was added to the extracts for the determination of the recovery of the internal standards added before. The analysis was performed using liquid chromatography and tandem mass spectrometry (LC/MS-MS). For each substance, two isotope masses were measured. The quantification was carried out with the use of internal and external standards. As values for PFOA rarely exceeded the limit of quantification, only the results for PFOS are presented in this publication.

\section{HCB}

Before extraction, the eel samples were dried by thorough mixing with anhydrous sodium sulfate and homogenised. A mixture of ${ }^{13} \mathrm{C}_{12}$-labelled internal standards was added to the samples before the extraction procedure. After spiking, the samples were extracted with a mixture of appropriate polar and non-polar solvents for ultratrace-analyses (e.g. hexane/acetone). The extraction was followed by a cleanup procedure using a column system (involving florisil resp. alumina). Further ${ }^{13} \mathrm{C}_{12^{-}}$ labelled internal standards were added to the extract for the determination of the recovery of the internal standards added before. The measurement was taken by means of HRGC/HRMS. For each substance, two isotope masses were measured. The quantification was carried with the use of internal and external standards.

\section{Mercury $(\mathrm{Hg})$}

Eel homogenate was digested by means of microwave using nitric acid. After reduction of mercury compounds by Tin(II)-chloride, the total mercury content was determined by means of cold vapor atomic absorption spectrometry (CV-AAS) following DIN EN 13806.

\section{Sampling of suspended matter}

Sampling and analysis of suspended matter was carried out by LANUV NRW as part of a separate surveillance monitoring program.

Suspended matter was collected using a flow through pump (Carl Padberg Cepa Z 61, Lahr, Germany) which was deposited in the water approximately $0.5 \mathrm{~m}$ below the surface. The time necessary to collect sufficient material was estimated by measuring the turbidity of the water (WTW IQ Sensor Net, System 184 with sensor with VISOTurb 700/Q, Weilheim, Germany). Usually, the pump collected material over 21 to $24 \mathrm{~h}$ with a flow rate of 1,000 to $1,100 \mathrm{l} / \mathrm{hr}$. The material was weighed in the field and transported refrigerated to the lab where it was freeze-dried, ground by a grinding mill equipped with a zirconium dioxide mortar and pestles (KM1, Retsch, Haan, Germany) and sieved for the $63-\mu \mathrm{m}$ fraction.

Data for suspended matter were available as annual means of usually between two and five individual samples per site. As sampling sites were sampled in different years, values for suspended matter were calculated as means for all annual means available between 2005 and 2012 (3 to 8 values).

\section{Analysis of suspended matter PBDEs}

PBDEs in suspended matter were identified using ${ }^{13} \mathrm{C}_{12}$ standards purchased from LGC Standards, Wesel, Germany. PBDEs were analysed according to DIN EN ISO 22032.

In brief, PBDEs were extracted with toluene from the freeze-dried $<63-\mu \mathrm{m}$ fraction of the suspended matter using Soxhlet extraction. Subsequently, the crude extracts were purified using multi-layer column chromatography with silica gel. Activated alumina was used as a second purification step. Subject to the grade of purification, these steps were repeated. The purified extracts were analysed by gas chromatography and mass spectrometry (GCMS Thermo Finnigan 2000, Thermo Fisher Scientific, Bremen, Germany).

\section{$P C D D / P C D F$ s and $P C B s$}

Quantification of PCDD/PCDFs and PCBs in suspended matter was performed using isotope dilution analysis according to EN 1948 part 2, 3 and 4 . The ${ }^{13} \mathrm{C}_{12}$ standards were purchased from Cambridge Isotopes Laboratories (Andover, USA).

In brief, the freeze-dried $<63-\mu \mathrm{m}$ fraction of the suspended matter was extracted with toluene using Soxhlet extraction. Prior to extraction, the samples were spiked with ${ }^{13} \mathrm{C}_{12}$-quantification standard mixtures. The crude sample extracts were subjected to a cleanup procedure consisting of a solid-phase multi-layer column chromatography with silica modified with $44 \% \mathrm{H}_{2} \mathrm{SO}_{4}, 33 \%$ $\mathrm{NaOH}$ or $10 \% \mathrm{AgNO}_{3}$. Furthermore, PCBs and PCDD/ PCDFs were separated using basic alumina. Subsequently, the eluates were concentrated via rotary evaporation and nitrogen flow to a final volume of approximately 10 to $20 \mu \mathrm{l}$ (PCDD/PCDF) or $100 \mu \mathrm{l}$ (PCB). After addition of recovery standards, PCDD/PCDFs and dl-PCB were analysed using high-resolution gas spectrometry (model 6890 Series 2, Agilent, Santa Clara, USA) and mass spectrometry (model DFS, Thermo Fisher Scientific, Bremen, 
Germany). Indicator PCBs were analysed using gas chromatography (model 6890 N, Agilent, Santa Clara, USA) and low-resolution mass spectrometry (model $5973 \mathrm{~N}$, Agilent, Santa Clara, USA). A detailed description of the analytical method can be found in Klees et al. [62].

\section{Quality assurance \\ Analysis of eels}

Quality control for the analysis of PCDD/PCDFs and PCBs was carried out in accordance with EU Regulation $1883 / 2006$. According to these requirements, the limit of quantification (LOQ) of an individual congener was the concentration of an analyte in the extract of a sample which produces an instrumental response at two different ions to be monitored with a signal/noise $(\mathrm{S} / \mathrm{N})$ ratio of $3: 1$ for the less sensitive signal and fulfillment of the basic requirements such as, e.g. retention time, isotope ratio according to the determination procedure as described in EPA method 1613 revision B. Additionally, the recoveries of the individual ${ }^{13} \mathrm{C}_{12}$-labelled internal standards were checked to be in the range of $60 \%$ to $120 \%$. Lower or higher recoveries for individual congeners were accepted on the condition that their contribution to the TEQ value did not exceed $10 \%$ of the total TEQ value. The analytical system was calibrated using an eight-point calibration, followed by checking with single calibrations in regular intervals within each measuring sequence. Quantification of the individual PCDD/ PCDF and PCB congeners was based on daily generated responses. Method blanks including extraction, cleanup and measuring were routinely monitored. Furthermore, precision and accuracy were checked by analysing inhouse quality assurance pool samples within each batch of samples consisting of not more than 12 samples. The pool sample used in this project consisted of combined fish meal specimens having been determined beforehand with the quality of the analysis data being assured by means of control charts. In addition, precision and accuracy were weekly checked by analysing the certified reference material EDF-2525 (provided by Community Bureau of Reference - BCR, Belgium).

Quality control for the analysis of PBDEs was carried out as follows: next to the comparison of the retention time between native and ${ }^{13} \mathrm{C}_{12}$-labelled analytes (including ${ }^{13} \mathrm{C}_{12}$-BDE-209), relative isotope ratios were considered with a tolerance of $20 \%$ for peak identification. Limits of detection (LOD) were reached if peaks showed signals to be three times the baseline noise, and LOQ were set to be ten times the baseline noise. Additionally, the standard recovery rates of ${ }^{13} \mathrm{C}_{12}$-labelled quantification standards were checked to be in the range of $50 \%$ to $120 \%$. Special attention with regard to recovery rates and peak shape was paid to BDE-209. The analytical system was calibrated using a ten-point calibration, followed by checking with single calibrations in regular intervals within each measuring sequence. Quantification of the individual PBDE congeners was based on daily generated responses. Method blanks including extraction, cleanup and measuring were monitored in parallel to each batch of samples consisting of not more than 12 single samples. Furthermore, precision and accuracy were checked by analysing in-house quality assurance pool samples within each batch of samples. The pool sample used in this project consisted of combined fish oil specimens having been determined beforehand with the quality of the analysis data being assured by means of control charts. In addition, precision and accuracy were weekly checked by analysing the certified reference material EDF-2525 (provided by Community Bureau of Reference - BCR, Belgium).

The quality control for the analysis of HCB and PFOS/ PFOA was carried out similarly to the quality control measures applied to the analysis of PBDEs. For HBC, the analytical system was calibrated using a nine-point calibration. Precision and accuracy were checked by analysing in-house quality assurance pool samples consisting of combined feeding stuff specimens as well as certified standard solutions and also on a weekly basis by analysing the certified reference material EDF-2525 (provided by Community Bureau of Reference - BCR, Belgium). For PFOS/PFOA, in addition to retention time and relative isotope ratios, the ratio of the signal intensities of the two detected transitions was checked. The standard recovery rates of ${ }^{13} \mathrm{C}_{12}$-labelled quantification standards were checked to be in the range of $50 \%$ to $150 \%$. Precision and accuracy were checked by analysing homogenised fish material of a previous inter-laboratory testing study.

For quality control of the analysis of mercury method blanks as well as internal reference material being monitored by means of a control chart were checked.

\section{Analysis of suspended matter}

Quality control for the analysis of PCBs and PCDD/ PCDFs was carried out in accordance with DIN EN 1948 3-4. Here, next to the comparison of the retention time between native and ${ }^{13} \mathrm{C}_{12}$-labelled analytes, relative isotope ratios were considered with a tolerance of $20 \%$ for peak identification as additional criteria. LOD were reached if peaks showed to be three times the baseline noise, and LOQ were set to be ten times the baseline noise. Additionally, the standard recovery rates of ${ }^{13} \mathrm{C}_{12^{-}}$ labelled quantification standards were checked. The analytical system was calibrated using a five-point calibration, and quantification for the individual PCB and PCDD/ PCDF congeners was based on daily generated response. The calibration and also the generated response factors were considered to be valid as long as a deviation under $20 \%$ for a single calibration was determined [DIN EN 19481]. Method blanks including extraction, cleanup and 
analysis were routinely monitored. Furthermore, precision and accuracy were checked by analysing the NIST Standard Reference Material (SRM) 1649a.

Quality control for the analysis of PBDEs was carried out similarly to the quality control measures for PBDE analysis in biota with the following exceptions: limits of quantification were determined by comparing the signal/ noise in 10 real suspended matter samples and a quantification limit $\geq 6^{*}$ baseline signal (600-ZUA-VA-007). The standard recovery rates of ${ }^{13} \mathrm{C}_{12}$-labelled quantification standards were checked to be in the range of $50 \%$ to $120 \%$. The analytical system was calibrated using a five-point calibration, checked in each series of measurements by five standard solutions. Method blanks including extraction, cleanup and measuring were monitored in parallel to each batch of samples consisting of not more than 6 single samples with a tolerance of $\leq 1 / 3$ of quantification limit.

\section{Statistical analysis}

Statistical analysis was performed using the statistical software SAS 9.2 and SPSS 19. The Shapiro-Wilk test demonstrated that the data of the contaminants were not normally distributed. For differences between mean contaminant concentration (least squares means) of sampling sites, an analysis of covariance with age and lipid content as covariates and Tukey's test were performed $(\alpha=0.1)$. Significant differences between sampling sites were checked using the Kruskall-Wallis test. For correlations between biometric parameters and contaminants Pearson's correlation coefficients were used. As $n>100$, an approximately normal distribution was assumed and significance levels could be calculated. To test the influence of biometric parameters on contaminant concentration, an analysis of covariance was performed between each biometric parameter and the contaminants after eliminating the influence of the sampling sites.

To analyse the differences of mean contaminant concentrations in different parasite classes, an analysis of variance was performed followed by Tukey's test. To compare the parasite patterns of the sampling sites, a Monte Carlo simulation of Fisher's exact test was used. Logistic regressions between parasite infection and biometric parameters or pollutants were calculated. For all the tests, apart from Tukey's test on differences on mean contaminant concentration of sampling sites, a significance level of $\alpha=0.05$ was set.

\section{Competing interests}

The authors declare that they have no competing interests.

\section{Authors' contributions}

BG compiled and analysed the data. FJS participated in the study coordination and carried out the biometric investigations. GS performed the statistical analyses. The final manuscript was read and approved by all authors.

\section{Acknowledgements}

The authors wish to acknowledge the help of Peter Perkons, LANUV, with preparation of the figures and tables. They would also like to thank Nina Lohmann, Eurofins GfA Lab Service, Germany, and Ernst Hiester, Marcel Klees, Klaus Sielex and Paul Bachhausen (all LANUV) for revision of the chapter on analytical methods.

Received: 5 June 2014 Accepted: 28 September 2014

Published online: 17 October 2014

\section{References}

1. ICES: Report of the 2013 Session of the Joint EIFAC/ICES Working Group on Eels. 18-22 March 2013, Sukarietta, Spain, 4-10 September 2013, ICES CM 2013/ACOM:18. Copenhagen: ICES; 2013.

2. ICES: Report of the 2006 session of the Joint EIFAC/ICES Working Group on Eels, FAO European Inland Fisheries Advisory Commission; International Council for the Exploration of the Sea. Rome, 23-27 January 2006. EIFAC Occasional Papaer No. 38. ICES CM 2006/ACFM:16. Rome: FAO/Copenhagen; 2006:352.

3. Belpaire C, Goemans G, Geeraerts C, Quataert P, Parmentiert K, Hagel P, De Boer J: Decreasing eel stocks: survival of the fattest? Ecol Freshw Fish 2009, 18:297-314.

4. Palstra AP, Heppener D, van Ginneken V, Székely C, van den Thillart GEEJM: Swimming performance of silver eels is severely impaired by the swim-bladder parasite Anguillicola crassus. J Exp Mar Biol Ecol 2007, 352:244-256.

5. Geeraerts C, Focant JF, Eppe G, de Pauw E, Belpaire C: Reproduction of European eel jeopardised by high levels of dioxins and dioxin-like PCBs? Sci Total Environ 2011, 409:4039-4047.

6. Corsi I, Mariottini M, Badesso A, Caruso T, Borghesi N, Bonacci S, lacocca A, Focardi S: Contamination and sub-lethal toxicological effects of persistent organic pollutants in the European eel (Anguilla anguilla) in the Orbetello lagoon (Tuscany, Italy). Hydrobiologia 2005, 550:237-249.

7. Blanchet-Letrouvé I, Zalouk-Vergnoux A, Vernisseau A, Couderc M, Le Bizec $B$, Elie P, Herrenknecht C, Mouneyrac C, Poirier L: Dioxin-like, non-dioxin like PCB and PCDD/F contamination in European eel (Anguilla anguilla) from the Loire estuarine continuum: spatial and biological variabilities. Sci Total Environ 2014, 472:562-571.

8. Geeraerts C, Belpaire C: The effects of contaminants in European eel: a review. Ecotoxicology 2010, 19:239-266.

9. van Ginneken V, Palstra A, Leonards P, Nieveen M, van den Berg H, Flik G, Spanings T, Niemantsverdriet $P$, van den Thillart G, Murk A: PCBs and the energy cost of migration in the European eel (Anguilla anguilla L.). Aquat Toxicol 2009, 92:213-220.

10. Hamers T, Kamstra JH, Sonneveld E, Murk AJ, Kester MH, Andersson PL, Legler J, Brouwer A: In vitro profiling of the endocrine-disrupting potency of brominated flame retardants. Toxicol Sci 2006, 92:157-173.

11. Legler J: New insights into the endocrine disrupting effects of brominated flame retardants. Chemosphere 2008, 73:216-222.

12. Ren X, Guo L: Molecular toxicology of polybrominated diphenyl ethers: nuclear hormone receptor mediated pathways. Environ Sci Process Impacts 2013, 15:702.

13. Muirhead EK, Skillman AD, Hook SE, Schultz IR: Oral exposure of BDE-47 in fish: toxicokinetics and reproductive effects in Japanese medaka (Oryzias latipes) and fathead minnows (Pimephales promelas). Environ Sci Technol 2006, 40:523-528.

14. Hoff $\mathrm{P}$, van Dongen W, Esmans E, Blust R, de Coen W: Evaluation of the toxicological effects of perfluorooctane sulfonic acid in the common carp (Cyprinus carpio). Aquat Toxicol 2003, 62:349-359.

15. Roland K, Kestemont P, Loos R, Tavazzi S, Paracchini B, Belpaire C, Dieu M, Raes $\mathrm{M}$, Silvestre F: Looking for protein expression signatures in European eel peripheral blood mononuclear cells after in vivo exposure to perfluorooctane sulfonate and a real world field study. Sci Total Environ 2014, 468-469:958-967.

16. Hoff $P$, Van Campenhout $K$, Van de Vijver K, Covaci A, Bervoets L, Moens L, Huyskens G, Goemans G, Belpaire C, Blust R: Perfluorooctane sulfonic acid and organohalogen pollutants in liver of three freshwater fish species in Flanders (Belgium): relationships with biochemical and organismal effects. Environ Pollut 2005, 137:324-333.

17. Carlson E, Zelikoff JT: The immune system of fish: a target organ of toxicity. In The Toxicology of Fishes. Edited by Di Giulio RT, Hinton DE. Boca Raton: CRC Press; 2008:489-529. 
18. Maes GE, Raeymaekers J, Hellemans B, Geeraerts C, Parmentier K, De Temmerman L, Volckaert F, Belpaire C: Gene transcription reflects poor health status of resident European eel chronically exposed to environmental pollutants. Aquat Toxicol 2013, 126:242-255.

19. Stachel B, Christoph EH, Goetz R, Herrmann T, Krueger F, Kuehn T, Lay J, Loeffler J, Päpke O, Reincke H, Schröter-Kermani C, Schwartz R, Steeg E, Stehr D, Uhlig S, Umlauf G: Dioxins and dioxin-like PCBs in different fish from the river Elbe and its tributaries, Germany. J Hazard Mater 2007, 148:199-209.

20. Tapie N, Le Ménach K, Pasquaud S, Elie P, Devier MH, Budzinski H: PBDE and PCB contamination of eels from the Gironde estuary: from glass eels to silver eels. Chemosphere 2011, 83:175-185.

21. Pujolar JM, Milan M, Marino IAM, Capoccioni F, Ciccoti E, Belpaire C, Covaci A, Malarvannan G, Patarnello T, Bargelloni L, Zane L, Maes GE: Detecting genome-wide gene transcription profiles associated with high pollution burden in the critically endangered European eel. Aquat Toxicol 2013, 132-133:157-164.

22. Sühring R, Möller A, Freese M, Pohlmann J-D, Wolschke H, Sturm R, Xie Z, Hanel R, Ebinghaus R: Brominated flame retardants and dechloranes in eels from German rivers. Chemosphere 2013, 90:118-124.

23. Macgregor K, Oliver IW, Harris L, Ridgway IM: Persistent organic pollutants (PCB, DDT, HCH, HCB \& BDE) in eels (Anguilla anguilla) in Scotland: current levels and temporal trends. Environ Pollut 2010, 158:2402-2411.

24. Maes J, Belpaire C, Goemans G: Spatial variations and temporal trends between 1994 and 2005 in polychlorinated biphenyls, organochlorine pesticides and heavy metals in European eel (Anguilla anguilla L.) in Flanders, Belgium. Environ Pollut 2008, 153:223-237.

25. Noël L, Chekri R, Millour S, Merlo M, Leblanc J, Guérin T: Distribution and relationships of $\mathrm{As}, \mathrm{Cd}, \mathrm{Pb}$ and $\mathrm{Hg}$ in freshwater fish from five French fishing areas. Chemosphere 2013, 90:1900-1910.

26. Hloušková V, Lanková D, Kalachová K, Hrádková P, Poustka J, Hajšlová J, Pulkrabová J: Occurrence of brominated flame retardants and perfluoroalkyl substances in fish from the Czech aquatic ecosystem. Sci Total Environ 2013, 461-462:88-98.

27. McHugh B, Poole R, Corcoran J, Anninou P, Boyle B, Joyce E, Barry Foley M, McGovern E: The occurrence of persistent chlorinated and brominated organic contaminants in the European eel (Anguilla anguilla) in Irish waters. Chemosphere 2010, 79:305-313.

28. Miniero R, Guandalini E, Dellatte E, lacovella N, Abate V, De Luca S, lamiceli AL, di Domenico A, De Felip E: Persistent organic pollutants (POPs) in fish collected from the urban tract of the river Tiber in Rome (Italy). Ann Ist Super Sanita 2011, 47:310-315.

29. Knutzen J, Bjerkeng B, Næs K, Schlabach M: Polychlorinated dibenzofurans/dibenzo-p-dioxins (PCDF/PCDDs) and other dioxin-like substances in marine organisms from the Grenland fjords, S. Norway, 1975-2001: present contamination levels, trends and species specific accumulation of PCDF/PCDD congeners. Chemosphere 2003, 52:745-760.

30. Palstra AP, van Ginneken VJ, Murk AJ, van den Thillart GE: Are dioxin-like contaminants responsible for the eel (Anguilla anguilla) drama? Naturwissenschaften 2006, 93:145-148.

31. Heinisch E, Kettrup A, Bergheim W, Wenzel S: Persistent chlorinated hydrocarbons (PCHCs), source-orientated monitoring in aquatic media. 6. Strikingly high contaminated sites. Fresen Environ Bull 2007, 16:1248-1273.

32. Detzel A, Patyk A, Fehrenbach H, Franke B, Giegrich J, Lell M, Vogt R: Ermittlungen von Emissionen und Minderungsmaßnahmen für persistente organische Schadstoffe in der Bundesrepublik Deutschland, Forschungsbericht 295 44 365, UBA-FB 98-115, UBA-Texte 74/98. Berlin: Umweltbundesamt; 1998

33. de Boer J, Dao QT, van Leeuwen SP, Kotterman MJ, Schobben JH: Thirty year monitoring of PCBs, organochlorine pesticides and tetrabromodiphenylether in eel from The Netherlands. Environ Pollut 2010, 158:1228-1236.

34. Byer JD, Lebeuf M, Alaee M, Brown SR, Trottier S, Backus S, Keir M, Couillard CM, Casselman J, Hodson PV: Spatial trends of organochlorinated pesticides, polychlorinated biphenyls, and polybrominated diphenyl ethers in Atlantic Anguillid eels. Chemosphere 2013, 90:1719-1728.

35. Malarvannan G, Belpaire C, Geeraerts C, Eulaers I, Neels H, Covaci A: Assessment of persistent brominated and chlorinated organic contaminants in the European eel (Anguilla Anguilla) in Flanders, Belgium: levels, profiles and health risk. Sci Total Environ 2014, 482-483:222-233.

36. Kammann U, Brinkmann M, Freese M, Pohlmann J-D, Stoffels S, Hollert H, Hanel R: PAH metabolites, GST and EROD in European eel (Anguilla anguilla) as possible indicators for eel habitat quality in German rivers. Environ Sci Pollut Res 2013, 21:2519-2530.

37. Heinisch E, Kettrup A, Bergheim W, Martens D, Wenzel S: Persistent chlorinated hydrocarbons (PCHC), source-orientated monitoring in aquatic media. 4. The chlorobenzenes. Fresen Environ Bull 2006, 15:148-169.

38. Roosens L, Dirtu AC, Goemans G, Belpaire C, Gheorghe A, Neels H, Blust R, Covaci A: Brominated flame retardants and polychlorinated biphenyls in fish from the river Scheldt, Belgium. Environ Int 2008, 34:976-983.

39. Tomy GT, Palace VP, Halldorson T, Braekevelt E, Danell R, Wautier K, Evans B, Brinkworth L, Fisk AT: Bioaccumulation, biotransformation and biochemical effects of brominated diphenyl ethers in juvenile Lake Trout (Salvelinus namaycush). Environ Sci Technol 2004, 38:1496-1504.

40. Kierkegaard A, Balk L, Tjärnlund U, De Wit CA, Jansson B: Dietary uptake and biological effects of decabromodiphenyl ether in rainbow trout (Oncorhynchus mykiss). Environ Sci Technol 1999, 33:1612-1617.

41. LANUV: Verbreitung von PFT in der Umwelt. Ursachen - Untersuchungsstrategie Ergebnisse-Maßnahmen. LANUV Fachbericht Nr. 34. Recklinghausen: LANUV; 2011:118.

42. Linde AR, Sanchez-Galan S, Garcia-Vazquez E: Heavy metal contamination of European eel (Anguilla anguilla) and brown trout (Salmo trutta) caught in wild ecosystems in Spain. J Food Prot 2004, 67:2332-2336.

43. Eira C, Torres J, Miquel J, Vaqueiro J, Soares A, Vingada J: Trace element concentrations in Proteocephalus macrocephalus (Cestoda) and Anguillicola crassus (Nematoda) in comparison to their fish host, Anguilla anguilla in Ria de Aveiro, Portugal. Sci Total Environ 2009, 407:991-998.

44. Sandheinrich MB, Wiener JG: Methylmercury in freshwater fish: recent advances in assessing toxicity of environmentally relevant exposures. In Environmental Contaminants in Biota: Interpreting Tissue Concentrations. Edited by Beyer BN, Meador JP. Boca Raton: CRC Press; 2011:169-190.

45. Müller $L$, Neugebauer F, Fromme H: Levels of coplanar and non-coplanar polychlorinated biphenyls (PCB) in eel and sediment samples from Berlin/Germany. Organohalogen Compd 1999, 43:397-400.

46. Ashley JT, Horwitz R, Steinbacher JC, Ruppel B: A comparison of congeneric PCB patterns in American eels and striped bass from the Hudson and Delaware River estuaries. Mar Pollut Bull 2003, 46:1294-1308

47. Harrad SJ, Smith DJT: Bioaccumulation factors (BAFs) and biota to sediment accumulation factors (BSAFs) for PCBs in pike and eels. Environ SC Pollut Res Int 1997, 4:189-193.

48. Nunes M, Marchand P, Vernisseau A, Le Bizec B, Ramos F, Pardal MA: PCDD/ Fs and dioxin-like PCBs in sediment and biota from the Mondego estuary (Portugal). Chemosphere 2011, 83:1345-1352.

49. Lepom P, Karasyova T, Sawal G: Occurrence of polybrominated diphenyl ethers in freshwater fish from Germany. Organohalogen Compd 2002. 58:209-212.

50. Sühring R, Byer J, Freese M, Pohlmann J-D, Wolschke H, Möller A, Hodson PV, Alaee $M$, Hanel R, Ebinghaus R: Brominated flame retardants and Dechloranes in European and American eels from glass to silver life stages. Chemosphere 2014, 116:104-111.

51. Roosens L, Geeraerts C, Belpaire C, Van PI, Neels H, Covaci A: Spatial variations in the levels and isomeric patterns of PBDEs and HBCDs in the European eel in Flanders. Environ Int 2010, 36:415-423.

52. Stapleton HM, Alaee M, Letcher RJ, Baker JE: Debromination of the flame retardant decabromodiphenyl ether by juvenile carp (Cyprinus carpio) following dietary exposure. Environ Sci Technol 2004, 38:112-119.

53. Stapleton HM, Brazil B, Holbrook RD, Mitchelmore CL, Benedict R, Konstantinov A, Potter D: In vivo and in vitro dibromination of decabromodiphenyl ether (BDE 209) by juvenile rainbow trout and common carp. Environ Sci Technol 2005, 40:4653-4658.

54. Dominguez AA, Law RJ, Herzke D, de Boer J: Bioaccumulation of brominated flame retardants. In Brominted Flame Retardants. Edited by Eljarrat E, Barceló D. Berlin: Springer; 2011:141-185.

55. Mariottini M, Corsi I, Della Torre C, Caruso T, Bianchini A, Nesi I, Focardi S: Biomonitoring of polybrominated diphenyl ether (PBDE) pollution: a field study. Comp Biochem Physiol C Toxicol Pharmacol 2008, 148:80-86.

56. LANUV: Verzehrsempfehlung Aale vom 16.07.2012. [www.lanuv.nrw.de/ verbraucher/warnungen/verzehr.htm]

57. ICES: Annex 4. Manual for the Ageing of Atlantic Eel. Otolith preparation methodologies, age interpretation and image storage. In ICES Workshop on Age Reading of European and AmericanEel (WKAREA), 20-24 April 2009, Bordeaux, France. ICES CM 438 2009:ACOM 48. Copenhagen: ICES; 2009:59. 
58. Durif C, Dufour S, Elie P: The silvering process of Anguilla anguilla: a new classification from the yellow resident to the silver migrating stage. J Fish Biol 2005, 66:1025-1043.

59. Neugebauer F, Schröter-Kermani C, Päpke O, Steeg W: Analytical experiences with the German environmental specimen bank: time trends of PCDD/F and DL_PCB in bream (Abramis brama) caught in German rivers. Organohalogen Compd 2011, 73:1340-1343.

60. Van den Berg M, Birnbaum LS, Denison M, de Vito M, Fraland W, Feeley M, Fiedler H, Hakansson H, Hanberg A, Haws L, Roes M, Safe S, Schrenk D, Tohyama C, Tritscher A, Tuomisto J, Tysklind M, Walker N, Peterson RE: RE: World Health Organization reevaluation of human and mammalian toxic equivalency factors for dioxins and dioxin-like compounds. Toxicol Sci 2005, 2006(93):223-241.

61. Päpke O, Schröter-Kermani C, Stegemann D, Neugebauer F, Ebsen F: Analytical experiences with the German Environmental Specimen Bank: polybrominated diphenyl ethers in deer liver samples and corresponding soils. Organohalogen Compd 2011, 73:416-419.

62. Klees M, Hiester E, Bruckmann P, Schmidt TC: Determination of polychlorinated biphenyls and polychlorinated dibenzo-p-dioxins and dibenzofurans by pressurized liquid extraction and gas chromatography coupled to mass spectrometry in street dust samples. J Chromatogr A 2013, 1300:17-23.

doi:10.1186/s12302-014-0026-1

Cite this article as: Guhl et al: Contaminant levels in the European eel (Anguilla anguilla) in North Rhine-Westphalian rivers. Environmental Sciences Europe 2014 26:26.

\section{Submit your manuscript to a SpringerOpen ${ }^{\circ}$ journal and benefit from:}

- Convenient online submission

- Rigorous peer review

- Immediate publication on acceptance

- Open access: articles freely available online

- High visibility within the field

- Retaining the copyright to your article 